\title{
The Determinant of Decision to Visit Tourism Destination
}

\author{
Nyoman Surya Wijaya1* ${ }^{*}$ I Wayan Eka Sudarmawan², I Gusti Made Sukaarnawa ${ }^{3}$ \\ 1,2,3 Institut Pariwisata dan Bisnis Internasional, Denpasar - Indonesia
}

\section{A R T I C L E I N F O}

Article history:

Received October, 182021

Received in revised form

November, 142021

Accepted November, 20 2021

Available online December, 252021

\section{Kata Kunci:}

Atribut-destinasi,

keputusan berkunjung

promosi, place-branding.

Keywords:

Attribute-destination,

decision-visit, promotion,

place-branding.

\begin{abstract}
A B S T R A K
Penelitian ini bertujuan untuk mengkaji tentang bagaimanakah keputusan berkunjung wisatawan ke destinasi wisata Pura Tirta Empul Tampaksiring Gianyar Bali. Variable Dependent yang digunakan dalam penelitian ini adalah Keputusan berkunjung, sedangkan Promosi, Atribut Destinasi dan Place Branding adalah variable Independent. Populasi dari penelitian adalah pengunjung yang datang ke Destinasi Wisata Pura Tirta Empul, sampel penelitian sebanyak 105 orang menggunakan Teknik accidental sampling, dengan pendekatan deskriptif kuantitatif, menggunakan alat analisis Partial Least Square (PLS) software SmartPLS. Hasil analisis menunjukkan promosi dan atribut destinasi berpengaruh positip dan signifikan terhadap place branding dengan nilai masing-masing 7,098 dan 6,626, promosi berpengaruh positip dan tidak signifikan terhadap keputusan berkunjung ke destinasi wisata dengan nilai 1,603, atribut destinasi berpengaruh positip dan signifikan terhadap keputusan berkunjung ke destinasi wisata dengan nilai 3.429 , place branding berpengaruh positip dan signifikan terhadap keputusan berkunjung ke destinasi wisata dengan nilai 4,646, pembentukan place branding lebih dominan dipengaruhi oleh atribut destinasi, dan pengambilan keputusan berkunjung ke destinasi wisata lebih dominan dipengaruhi oleh place branding. Place Branding berperan sebagai pemediasi penuh.
\end{abstract}

\section{A B S T R A C T}

This study aims to examine how the decision to visit tourists to tourist destinations Tirta Empul Temple Tampaksiring Gianyar Bali. The dependent variable used in this study is the decision to visit, while promotion, destination attributes and place branding are independent variables. The population of the study were visitors who came to the Tirta Empul Temple Tourism Destination, the research sample was 105 people using accidental sampling technique, with a quantitative descriptive approach, using analytical tools. Partial Least Square (PLS) software SmartPLS. The results of the analysis show promotion and destination attributes have a positive and significant effect on place branding with a value of 7.098 and 6.626, respectively, promotion has a positive and insignificant effect on decisions to visit tourist destinations with a value of 1.603, destination attributes have a positive and significant effect on decisions to visit tourist destinations with a value of 1.603. 3,429, place branding has a positive and significant effect on decisions to visit tourist destinations with a value of 4.646, the formation of place branding is more dominantly influenced by destination attributes, and decision making to visit tourist destinations is more dominantly influenced by place branding. Place Branding acts as a full mediator.

\footnotetext{
* Corresponding author.

E-mail : surya.wijaya@ipb-intl.ac.id (Nyoman Surya Wijaya)
} 


\section{Pendahuluan}

Undang Undang No. 10/2009 tentang Kepariwisataan, menjelaskan bahwa, yang dimaksud dengan pariwisata adalah berbagai macam kegiatan wisata yang didukung oleh berbagai fasilitas serta layanan yang disediakan masyarakat, pengusaha, Pemerintah dan Pemerintah Daerah. Lebih lanjut dalam UU tersebut juga dijelaskan bahwa, wisata merupakan kegiatan perjalanan yang dilakukan oleh seseorang atau sekelompok orang dengan mengunjungi tempat tertentu untuk tujuan rekreasi, pengembangan pribadi, atau mempelajari keunikan daya tarik wisata yang dikunjungi dalam jangka waktu sementara. Ditambahkan lagi Pariwisata berperan penting dalam memperkuat perekonomian, menciptakan pekerjaan dan kesempatan untuk pengembangan karir, mempromosikan pengembangan, memberikan layanan kepada pelanggan, dan meningkatkan kualitas hidup masyarakat. Pada gilirannya, ini akan mengurangi pengangguran dan kemiskinan, karena sektor pariwisata merupak sector industri yang padat karya (Eugenio-Martin, Martín Morales, \& Scarpa, 2004).

Pura Tirta Empul Tampaksiring merupakan objek wisata yang terletak di Kabupaten Gianyar Bali posisinya sangat dekat Ubud yang merupakan desa wisata terbaik di dunia dan kawasan wisata Tegallalang yang terkenal dengan sawah teraseringnya. Pura Tirta Empul Tampaksiring ini merupakan wisata yang mengandalkan air (untuk keperluan melukat) serta lebih menonjolkan kawasan persawahan yang asri serta beraneka ragam pepohonan yang tampak rindang, yang terkelola dalam organisasi petani lokal yang disebut subak, yang masih tetap terjaga kelestariannya sebagai upaya untuk penyelamatan lingkungan dan sosioculture.

Pura Tirta Empul telah diajukan sebagai warisan budaya dunia (Setiawan, 2011), dan telah menjadi warisan budaya dunia (WBD) per tanggal 29 Juni 2012 (Ardika, n.d.) (Windia11, Sumiyati, Tika, \& Sedana, n.d.) yang terletak di Desa Manukaya, Kecamatan Tampaksiring, Kabupaten Gianyar, Provinsi Bali. Pura Tirta Empul telah ditetapkan menjadi salah satu warisan budaya dunia dengan ciri khas dan keunikan tersendiri bila dibandingkan dengan tinggalan budaya lainnya. Dengan keunikan dan daya tariknya tersebut menjadikan Pura Tirta Empul menjadi sangat menarik bagi wisatawan, apalagi fungsi utamanya yaitu sebagai tempat suci dan tempat sembahyang bagi Umat Hindu masih tetap terjaga sampai saat ini. Ini salah satu indikator yang menjadikan Pura Tirta Empul sebagai destinasi wisata yang menarik untuk dikunjungi bagi wisatawan lokal maupun asing.

Objek wisata Pura Tirta Empul di Tampaksiring, menjadi tujuan wisata menarik bagi khalayak umum, terutama bagi siswa sekolah. Banyak sekolah mulai dari tingkat Sekolah Dasar sampai dengan Sekolah Menengah Atas, mengagendakan study tour ke Pura Tirta Empul khususnya pada liburan pasca semesteran. Selain menyuguhkan pemandangan pepohonan hijau nan rimbun juga lembah sungai Pakerisan dengan aliran airnya yang jernih dan sejuk, juga pengetahuan tentang peninggalan bersejarah mengenai situs arkeolog.

Pura Tirta Empul ini merupakan destinasi wisata alam dan sejarah yang ditawarkan Pulau Bali selain wisata pantai. Pura Tirta Empul di Tampaksiring Gianyar, Bali, sebagai salah satu tujuan wisata unggulan di Kabupaten Gianyar sangat menarik para wisatawan, maka tidak mengherankan kalau Objek wisata Pura Tirta Empul di Tampaksiring Gianyar banyak dikunjungi, selain objek wisata yang lainnya seperti Gua Gajah dan Gunung Kawi Sebatu. Keputusan dari Pemerintah Kabupaten Gianyar membuka kembali Destinasi Wisata Tirta Empul mulai tanggal 1 Juli 2020, maka penulis yakin penelitian ini layak untuk dilakukan. Seperti peryataan Bapak Sekda Kabupaten Gianyar yang diberitakan oleh (JarrakPost.com, 2020), pada hari Rabu 1 Juli 2020 bahwa:

“......kita semua berharap agar perekonomian kembali berjalan, dengan mulai dibukanya objek wisata Tirta Empul kita harapkan perekonomian kembali berputar, tetapi tetap ada syarat-syarat yang harus dipenuhi terlebih dahulu, yakni telah memenuhi persyaratan penerapan protokol kesehatan ......"

Terkait dengan hal-hal yang telah dipaparkan tersebut maka lebih lanjut dapat dijelaskan dari beberapa hasil penelitian terdahulu diketahui bahwa banyak faktor yang mempengaruhi wisatawan dalam berkunjung ke daerah/destinasi wisata. Beberapa faktor tersebut seperti faktor promosi, atribut obyek wisata, image konsumen atau faktor kebutuhan dan gaya hidup konsumen.

Tjiptono, (2012) mendefinisikan promosi adalah elemen bauran pemasaran yang berfokus pada upaya menginformasikan, membujuk, dan mengingatkan kembali konsumen akan merek dan produk perusahaan. Sedangkan menurut Buchory \& Saladin, (2010) promosi adalah salah satu unsur dalam bauran pemasaran perusahaan yang didayagunakan untuk memberitahukan, membujuk, dan mengingatkan tentang produk perusahaan. Dari pengertian tersebut promosi sangat erat kaitannya dengan informasi atau berkomunikasi antara penjual dan pembeli potensial yang bersifat menyebarkan informasi, mempengaruhi, membujuk, dan mengingatkan pasar sasaran untuk menciptakan permintaan atas produk barang atau jasa 
yang ditawarkan perusahaan. Komunikasi yang dimaksud adalah membagi ide, informasi atau perasaan audiens.

Berbicara atribut obyek wisata Tjiptono, (2008), menjelaskan bahwa, atribut produk adalah beberapa unsur dari produk yang merupakan salah satu hal penting bagi konsumen dan yang merupakan acuan pengambilan keputusan pembelian oleh konsumen, yang terdiri merek, kemasan, jaminan (garansi), dan pelayanan. Lebih lanjut Kotler, (2016) menyebutkan produk memiliki 5 tingkatan, yakni 1. Core Benefit The service or benefit the customer is really buying. 2. Basic Product The marketer must turn the core benefit into a basic product. 3. Expected Product A set of attributes and conditions buyers normally expect when they purchase this product. 4. Augmented Product The marketer prepares an augmented product that exceeds customer expectations. 5. Potential Product Which encompasses all the possible augmentations and transformations the product or offering might undergo in the future.

Kotler \& Keller, (2021) mendifinisikan bahwa, brand image sebagai persepsi mengenai sebuah merek sebagaimana direfleksikan oleh asosiasi merek yang terdapat dalam benak konsumen. Ditambahkan pula bahwa brand image menurut Henslowe, (2003) adalah kesan yang di dapat menurut tingkatan dari pengetahuan dan pengertian akan fakta mengenai orang, produk, situasi. Objek yang dimaksud berupa orang, organisasi, kelompok orang atau lainnya yang tidak diketahui. Image merupakan pandangan atau persepsi serta terjadinya proses akumulasi dari amanat kepercayaan yang diberikan oleh individu-individu, akan mengalami suatu proses cepat atau lambat membentuk suatu opini publik yang lebih luas dan abstrak.

Armstrong et al., (2006), mendifinisikan keputusan pembelian konsumen adalah membeli merek yang paling disukai dari berbagai alternatif yang ada. Namun terdapat dua faktor yang bisa berada antara niat pembelian dan keputusan pembelian. Faktor pertama adalah sikap orang lain dan faktor yang kedua adalah faktor situasional. Oleh karena itu, preferensi dan niat pembelian tidak selalu menghasilkan pembelian yang aktual. Pengambilan keputusan merupakan suatu kegiatan individu secara langsung terlibat dalam mendapatkan barang yang ditawarkan. Menurut Setiadi, (2003), mendefinisikan suatu keputusan yakni kegiatan yang melibatkan pilihan diantara dua atau lebih alternatif tindakan atau perilaku. Jadi keputusan selalu mensyaratkan pilihan diantara beberapa perilaku berbeda.

Informasi yang tersaji dari hasil penelitian tersebut sudah tentu menimbulkan masalah bagi para pemasar, apakah strategi pemasaran yang disusun harus mengutamakan promosi, mengedepankan atribut obyek wisata, atau berusaha keras untuk menciptakan image konsumen yang positif (Astrama \& Mahayasa, 2021)

Berdasarkan berita yang di-release NusaBali.com, (2019) pada tanggal 16 November 2019 pukul 08:45:51 dengan judul "Tiket Objek Naik, Tirta Empul Tetap Ramai” menyebutkan jumlah kunjungan pada September 2019 mencapai 772.289 orang, ini artinya meningkat dari periode sebelumnya di tahun yang sama yakni 767.418 orang, dimana jumlah tersebut merupakan pengunjung asing dan domestik. Dari jumlah tersebut untuk pengunjung asing tercatat dewasa sebanyak 611.397 orang dan anak-anak 20.195 orang, sementara untuk pengunjung domestik tercatat dewasa sebanyak 118.528 orang sedangkan untuk anak-anak sebanyak 17.298 orang. Hal ini sejalan dengan pernyataan yang disampaikan oleh AA Gde Putrawan (2019) Kepala Disparda Gianyar yang mengatakan bahwa:

“........Sesuai data memang tingkat kunjungan wisatawan ke Objek Wisata Tirta Empul terus meningkat setiap tahunnya. Kenaikan tarif tiket masuk memang tidak mempengaruhi niat wisatawan mendatangi objek wisata mata air itu. "Tidak ada pengaruh terhadap tarif, kunjungan wisatawan tetap meningkat setiap tahunnya......".

Agung Putrawan juga menyatakan bahwa:

“... Berdasarkan data kunjungan wisatawan ke Daya Tarik Wisata (DTW) Pura Tirta Empul, Desa Manukaya, Kecamatan Tampaksiring, Gianya memang kunjungan sepanjang 2019 ini sudah meningkat signifikan. Peningkatan signifikan tersebut kalau dibandingkan dengan bulan yang sama pada tahun sebelumnya, peningkatannya terjadi hampir disetiap bulannya. "Seperti memasuki Juli, Agustus dan September 2019, tingkat kunjungan wisatawan mencapai di atas 100.000 per bulan....."

Diakui, kondisi ini berbeda dengan objek wisata sejenis yang dikelola oleh Pemda Gianyar (objek wisata Candi Tebing Tegallinggah, Yeh Pulu, Alam Sidan, dan Gunung Kawi Sebatu). Berdasarkan data, kunjungan di sejumlah objek lain justru stagnan, bahkan jumlahnya masih jauh jika dibandingkan kunjungan di bulan yang sama pada tahun sebelumnya. Dari jumlah kunjungan itu, Dispar Kabupaten Gianyar terus menghitung pemasukan dari penjualan/retribusi tiket masuk semua objek wisata di Kabupaten Gianyar. Terhitung, mulai awal Nopember 2019 jumlah retribusi yang diperoleh sudah mencapai Rp 64,9 miliar, dari yang ditargetkan sebesar Rp. 15 miliar. Pencapaian retribusi yang begitu tinggi dari kunjungan wisata ini tidak terlepas karena kenaikkan harga tiket retribusi ke objek wisata yang ada di Kabupaten Gianyar sesuai dengan kebijakan Pemkab Gianyar. Penyesuaian ini tidak terlepas dari kenaikan harga tiket yang dilakukan pemerintah kabupaten lain yang terlebih dahulu menaikkan harga 
tiket masuk ke objek wisata yang dikelolanya. Sementara itu, untuk harga tiket objek berbeda diterapkan seperti tersaji dalam tabel 1 di bawah.

Tabel 1. Harga Tiket Pengunjung objek wisata Candi Tebing Tegallinggah, Yeh Pulu, Alam Sidan, dan Gunung Kawi Sebatu Per Tahun 2018

\begin{tabular}{clcl}
\hline Asing & \multicolumn{3}{c}{ Domestik } \\
\hline Anak-Anak & Dewasa & Anak-Anak & Dewasa \\
15.000 & 30.000 & 10.000 & 20.000 \\
\hline
\end{tabular}

Sumber: Pemda Gianyar 2018

Tiket masuk ke obyek wisata Tirta Empul, Goa Gajah dan Gunung Kawi Tampaksiring mengalami kenaikan berdasarkan pada peraturan Bupati Gianyar Nomor 129 Tahun 2018 tentang Peninjauan Tarif retribusi Tempat Rekreasi dan Olahraga, seperti Tabel 2 di bawah.

Tabel 2. Harga Tiket Pengunjung obyek wisata Tirta Empul, Goa Gajah dan Gunung Kawi Tampaksiring Per Tahun 2018

\begin{tabular}{cclcc}
\hline & Asing & \multicolumn{3}{c}{ Domestik } \\
\hline & Anak-Anak & Dewasa & Anak-Anak & Dewasa \\
Harga lama & 7.500 & 15.000 & 10.000 & 20.000 \\
Harga Baru & 25.000 & 50.000 & 15.000 & 30.000 \\
\hline
\end{tabular}

Sumber: Pemda Gianyar 2018

Demikian halnya yang dialami oleh pengelola obyek ekowisata Pura Tirta Empul di Tampaksiring, Terkendala dalam merumuskan strategi pemasaran yang sesuai dan tepat, supaya dapat meningkatkan jumlah wisatawan yang berkunjung ke objek wisata alam tersebut. Dibandingkan dengan laju peningkatan jumlah pengunjung yang datang ke Bali, jumlah kunjungan wisatawan ke obyek Pura Tirta Empul di Tampaksiring, cendrung mengalami trend penurunan, padahal Pura Tirta Empul di Tampaksiring merupakan obyek wisata yang sangat terkenal di Bali.

Terjadinya trend yang cendrung menurun dari jumlah kunjungan wisatawan ke obyek ekowisata Pura Tirta Empul di Tampaksiring dapat dijadikan indikasi kalau obyek ekowisata Pura Tirta Empul di Tampaksiring ada permasalahan yang sedang menyelimuti. Identifikasi terhadap permasalahan yang sedang dihadapi yang perlu segera dilakukan, apakah permasalahan terkait dengan promosi, atribut destinasi, atau brand image dari Obyek Wisata Pura Tirta Empul, ataukah jalinan dari faktor-faktor tersebut. Supaya dapat menjawab permasalahan tersebut maka perlu segera dilakukan penelitian untuk mengetahui strategi pemasaran yang tepat dalam menetapkan faktor yang mem-pengaruhi pengambilan keputusan pengunjung dalam mengunjungi obyek wisata Pura Tirta Empul.

Penelitian ini bertujuan untuk mencari tahu keputusan berkunjung wisatawan ke destinasi Wisata Tirta Empul Tampaksiring Gianyar yang diprediktor oleh promosi, atribut destinasi, dan place branding, sehingga kedepannya dapat ditentukan model pemasaran yang tepat oleh pengelola destinasi wisata Pura Tirta Empul khususnya pemerintah Kabupaten Gianyar.

\section{Metode}

Metode yang digunakan dalam penelitian ini adalah deskriptif kuantitatif, memadukan Model Strategi Pemasaran terkait dengan obyek wisata Pura Tirta Empul Tampaksiring, untuk selanjutnya dikombinasikan dengan kebijakan pemerintah Daerah Kabupaten Gianyar terkait dengan Pura Tirta Empul Tampaksiring sebagai obyek wisata yang dapat memuaskan wisatawan yang berkunjung. Menurut Hair et al., (2006) dalam mengunakan Teknik SEM dalam analisis data penelitian sebaiknya ukuran sample yang dipenuhi secara minimum berjumlah 100 atau 200 sampel, untuk teknik maximum likelihood estimation dan menyarankan agar ukuran sampel minimum adalah sebanyak 5 - 10 kali jumlah parameter yang diestimasi. Dalam penelitian ini terdapat 18 indikator (parameter yang diestimasi), maka sampel yang digunakan antara 90 - 180. Dalam penelitian ini jumlah sampel yang ditetapkan adalah sebanyak 105 dari populasi tak terhingga yang desebarkan kepada pengunjung, pengukuran dekstruktif untuk menghindari 
obyek yang dikorbankan dalam pengujian jangan sampai terlalu besar yang bisa merugikan. Kuesioner digunakan mengingat fokus dari penelitian ini berupa perspektif stakeholders terhadap kondisi objek penelitian. Alat Análisis data yang digunakan adalah Partial Least Square (PLS) menggunakan program aplikasi software SmartPLS3.0.

\section{Hasil dan pembahasan \\ a. Hasil penelitian}

Uraian secara singkat mengenai karakteristik responden yang datang ke tempat penelitian dan bersedia mengisi kuesioner sebanyak 150 responden meliputi antara lain; berdasarkan jenis kelamin, tercatat bahwa laki-laki sebanyak 54 orang atau sekitar 51,4\%, sementara untuk responden perempuan sebanyak 51 orang atau sekitar 48,6\%; berdasarkan umur, rentangan umur responden dibagi menjadi 3 yaitu usia 18-26 tahun sebanyak 18 orang atau 17,1\%, usia 27-44 tahun sebanyak 48 orang atau 45,7\%, dan usia 45 - 64 tahun sebayak 39 orang atau 37,1\%; berdasarkan daerah asal, berasal dari Kabupaten Badung-Bali 3 orang atau 2,9\%, Kota Bandung-Jabar 8 orang atau 7,6\%, Kota Bogor-Jabar 3 orang atau 2,9\%, Kabupaten Buleleng-Bali 2 orang atau 1,9\%, DKI Jakarta sebanyak 36 orang atau 34,3\%, Provinsi Lombok sebanyak 2 orang atau 1,9\%, dari Malang-Jawa Timur sebanyak 11 orang atau 10,5\%, Kota Manado Sulawesi Utara sebanyak 12 orang atau 11,4\%, Kota Singaraja-Bali sebanyak 9 orang atau 8,6\%, dan dari Kota Surabaya-Jawa Timur sebanyak 19 orang atau 18,1\%; karakteristik berdasarkan pendidikan, tercatat tingkat SMA sebanyak 24 orang atau 22,9\%, tingkat Diploma sebanyak 8 orang atau 7,6\%, tingkat S1 tercatat paling banyak yaitu 65 orang atau 61,9\%, dan berpendidikan S2 sebanyak 8 orang atau sebanyak7,6\%; berdasarkan pekerjaan, tercatat bahwa 2 orang atau 1,9\% pelajar, sebanyak 17 orang atau $16,2 \%$ adalah karyawan swasta, sebanyak 20 orang atau $19 \%$ sebagai PNS, sementara responden terbanyak adalah sebagai Wirausaha yakni sebanyak 66 orang atau $62,9 \%$.

Tabel 3. Persepsi Responden Terhadap Variabel Promosi

\begin{tabular}{|c|c|c|c|c|c|c|c|}
\hline \multirow{3}{*}{ Indikator } & \multicolumn{5}{|c|}{ Jumlah Dalam \% } & \multirow{3}{*}{ Apresiasi } & \multirow{3}{*}{$\begin{array}{l}\text { Rerata } \\
\text { (Mean) }\end{array}$} \\
\hline & \multicolumn{5}{|c|}{ Tingkat Penilaian Responden } & & \\
\hline & 1 & 2 & 3 & 4 & 5 & & \\
\hline $\mathrm{x} 1.1$ & 0,0 & 0,0 & 1,9 & 55,2 & 42,9 & 88,20 & 4,41 \\
\hline $\mathrm{x} 1.2$ & 0,0 & 0,0 & 0,0 & 50,5 & 49,5 & 89,90 & 4,50 \\
\hline $\mathrm{x} 1.3$ & 0,0 & 0,0 & 0,0 & 47,6 & 52,4 & 90,48 & 4,52 \\
\hline $\mathrm{x} 1.4$ & 0,0 & 0,0 & 0,0 & 49,5 & 50,5 & 90,10 & 4,50 \\
\hline Rerata & 0,0 & 0,0 & 0,5 & 50,7 & 48,8 & 89,67 & 4,48 \\
\hline
\end{tabular}

Tabel 4. Persepsi Responden Terhadap Variabel Atribut Destinasi

\begin{tabular}{|c|c|c|c|c|c|c|c|}
\hline \multirow{3}{*}{ Indikator } & \multicolumn{5}{|c|}{ Jumlah Dalam \% } & \multirow{3}{*}{ Apresiasi } & \multirow{3}{*}{ (Mean) } \\
\hline & \multicolumn{5}{|c|}{ Tingkat Penilaian Responden } & & \\
\hline & 1 & 2 & 3 & 4 & 5 & & \\
\hline $\mathrm{x} 2.1$ & 0,0 & 0,0 & 11,4 & 45,7 & 42,9 & 86,30 & 4,31 \\
\hline $\mathrm{x} 2.2$ & 0,0 & 0,0 & 3,8 & 45,7 & 50,5 & 89,34 & 4,47 \\
\hline $\mathrm{x} 2.3$ & 0,0 & 0,0 & 3,8 & 48,6 & 47,6 & 88,76 & 4,44 \\
\hline $\mathrm{x} 2.4$ & 0,0 & 0,0 & 5,7 & 57,1 & 37,1 & 86,20 & 4,31 \\
\hline $\mathrm{x} 2.5$ & 0,0 & 0,0 & 0,0 & 51,4 & 48,6 & 89,72 & 4,49 \\
\hline Rerata & 0,00 & 0,00 & 4,94 & 49,70 & 45,34 & 88,06 & 4,40 \\
\hline
\end{tabular}


Tabel 5. Persepsi Responden Terhadap Variabel Place Branding

\begin{tabular}{|c|c|c|c|c|c|c|c|}
\hline \multirow{3}{*}{ Indikator } & \multicolumn{5}{|c|}{ Jumlah Dalam \% } & \multirow{3}{*}{ Apresiasi } & \multirow{3}{*}{$\begin{array}{l}\text { Rerata } \\
\text { (Mean) }\end{array}$} \\
\hline & \multicolumn{5}{|c|}{ Tingkat Penilaian Responden } & & \\
\hline & 1 & 2 & 3 & 4 & 5 & & \\
\hline y1.1 & 0,0 & 0,0 & 17,1 & 43,8 & 39 & 84,30 & 4,22 \\
\hline y1.2 & 0,0 & 0,0 & 6,7 & 50,5 & 42,9 & 87,32 & 4,36 \\
\hline y1.3 & 0,0 & 0,0 & 4,8 & 52,4 & 42,9 & 87,70 & 4,38 \\
\hline y1.4 & 0,0 & 0,0 & 4,8 & 46,7 & 48,6 & 88,84 & 4,44 \\
\hline $\mathrm{y} 1.5$ & 0,0 & 0,0 & 10,5 & 41,9 & 47,6 & 87,42 & 4,37 \\
\hline Rerata & 0,00 & 0,00 & 8,78 & 47,06 & 44,20 & 87,12 & 4,36 \\
\hline
\end{tabular}

Tabel 6. Persepsi Responden Terhadap Variabel Keputusan Mengunjungi Destinasi Wisata

\begin{tabular}{|c|c|c|c|c|c|c|c|}
\hline \multirow{3}{*}{ Indikator } & \multicolumn{5}{|c|}{ Jumlah Dalam \% } & \multirow{3}{*}{ Apresiasi } & \multirow{3}{*}{$\begin{array}{l}\text { Rerata } \\
\text { (Mean) }\end{array}$} \\
\hline & \multicolumn{5}{|c|}{ Tingkat Penilaian Responden } & & \\
\hline & 1 & 2 & 3 & 4 & 5 & & \\
\hline y2.1 & 0,0 & 0,0 & 0,0 & 49,5 & 50,5 & 90,10 & 4,50 \\
\hline y2.2 & 0,0 & 0,0 & 0,0 & 57,1 & 42,9 & 88,58 & 4,43 \\
\hline y2.3 & 2,9 & 0,0 & 16,2 & 51,4 & 29,5 & 80,92 & 4,05 \\
\hline y2.4 & 0,0 & 0,0 & 0,0 & 60 & 40 & 88,00 & 4,40 \\
\hline Rerata & 0,73 & 0,00 & 4,05 & 54,50 & 40,73 & 86,90 & 4,35 \\
\hline
\end{tabular}

Uji Validitas pada penelitian ini, variabel promosi (X1), atribut destinasi (X2), place branding (Y1) dan keputusan berkunjung ke destinasi wisata (Y2) merupakan first order construct. Analisis uji validitas dan reliabilitas terhadap konstruk maka sangat diperlukan untuk menampilkan output hasil pengolahan data SEM Algorithm dengan software PLS 3.0 seperti tampak pada Gambar 1. berikut :

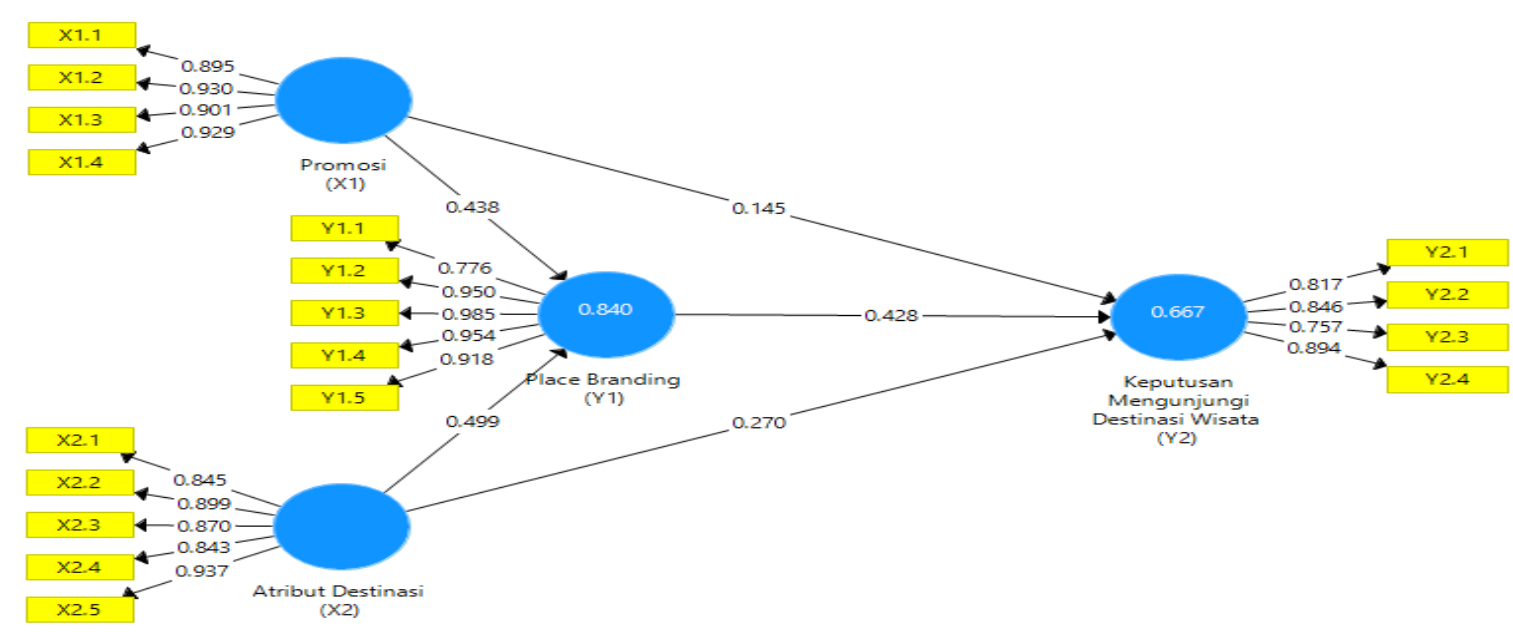

Gambar 1. Output SmartPLS 3.0 (Loading Factor dan Standardize Beta)

Dua hal pokok dalam melakukan Evaluasi Inner Model (Struktural Model), yaitu evaluasi kecocokan model (goodness of fit) dan evaluasi pengaruh variabel eksogen terhadap variabel endogen melalui pengujian hipotesis. Evaluasi pengaruh meliputi pengaruh langsung maupun pengaruh tidak langsung. 
Evaluasi kecocokan model (goodness of fit) dan evaluasi pengaruh variabel eksogen terhadap variabel endogen mengacu pada output SEM PLS bootstrapping seperti ditampilkan Gambar 2.

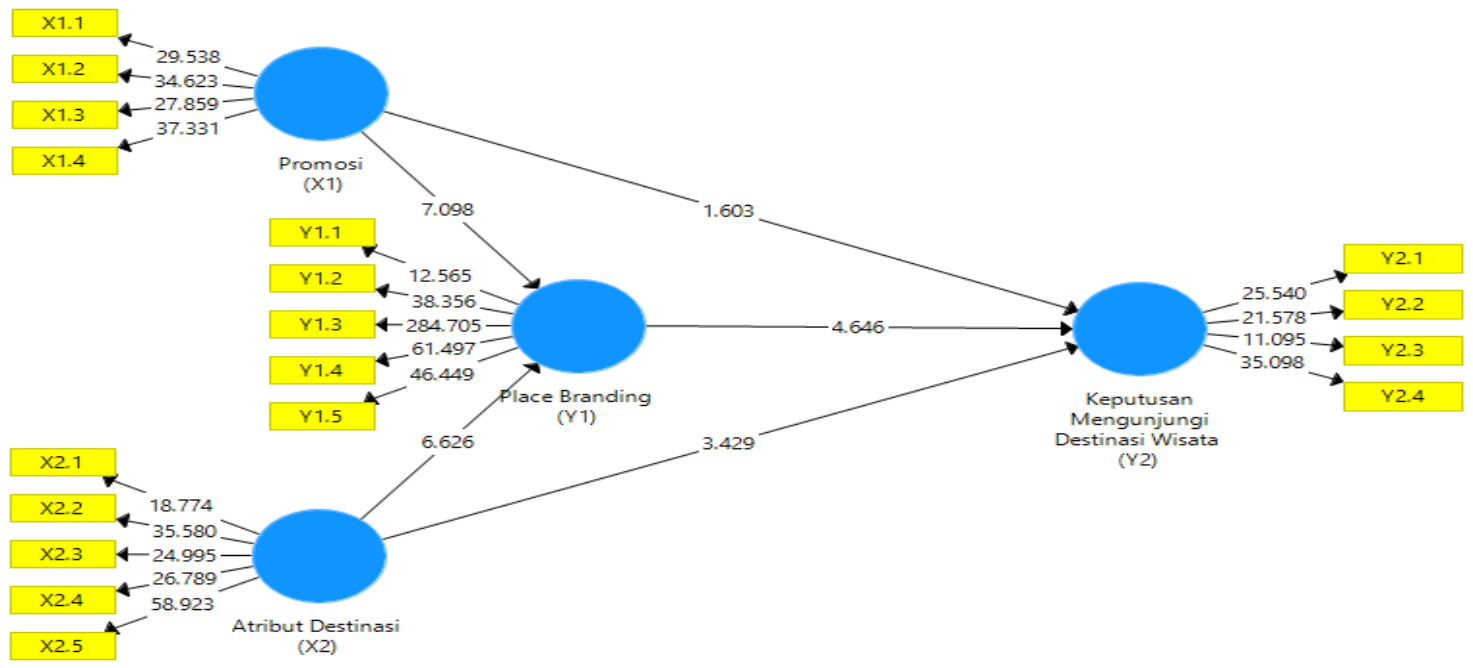

Gambar 2. Path Coefficient Model Bootstraping (Koefisien Tstatistik)

Variabel Eksogen pada Gambar 2 di atas, yaitu: promosi (X1) dan atribut destinasi (X2), terdapat satu variabel intervening yaitu place branding (Y1), serta satu buah variabel endogen, yaitu keputusan berkunjung ke destinasi wisata (Y2). Variabel endogen keputusan berkunjung ke destinasi wisata (Y2) memiliki tiga buah prediktor meliputi promosi (X1), atribut destinasi (X2) dan place pranding (Y1). Sedangkan, variabel intervening place branding (Y1) memiliki dua buah prediktor meliputi promosi (X1) dan atribut destinasi (X2). Pada Gambar 2, place branding (Y1) berperan sebagai variabel intervening.

\section{Pengujian Kecocokan Model (Evaluasi Goodness of Fit Inner Model)}

Model struktural hasil pengolahan PLS perlu dievaluasi dengan menggunakan R-square untuk setiap variabel dependen, dan $Q$ square predictive relevance untuk melihat efek konstruk laten eksogen terhadap variabel endogennya. Untuk keperluan evaluasi Goodness of Fit Inner Model ditampilkan Tabel 6 yang memuat koefisien R-square untuk setiap variabel endogen.

Tabel 6. Nilai R-square Variabel Place branding dan Variabel Keputusan Berkunjung ke Destinasi Wisata

\begin{tabular}{ll}
\hline Variabel & R Square \\
\hline Place Branding (Y1) & 0,840 \\
Keputusan Berkunjung ke Destinasi Wisata (Y2) & 0,667 \\
\hline
\end{tabular}

Tabel 6 menunjukkan nilai R-square 0,840 untuk variabel place branding (Y1) dan 0,667 untuk variabel keputusan berkunjung ke destinasi wisata (Y2). Artinya bahwa variasi perubahan variabel place branding dapat dijelaskan oleh variabel promosi dan atribut destinasi bersama-sama sebesar 84,0 persen. Sisanya yaitu 16,0 persen dijelaskan oleh faktor lain selain promosi dan atribut destinasi. Selanjutnya atas variabel keputusan berkunjung ke destinasi wisata (Y2) dapat dijelaskan oleh variabel promosi, atribut destinasi dan place branding adalah sebesar 66,7 persen. Sisanya senilai 33,3 persen dijelaskan oleh faktor lain selain tiga variabel tersebut.

Berdasarkan dua koefisien R2 pada Tabel 6 dapat pula dihitung besarnya koefisien Q2 atau Stone Geiser Q-Square test ((Stone, 1974); (Geisser, 1974) dan (Ghozali, 2011), yaitu:

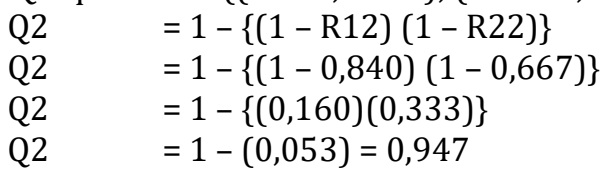

Hasil perhitungan memperoleh Q2 sebesar 0,947, sehingga dapat dikatakan model ini memiliki predictive prevelance yang kuat. Berarti sebagian besar dari variasi variabel dependent dapat dijelaskan 
oleh variabel yang disertakan pada model penelitian ini. Angka sebesar 0,947 atau predictive prevelance yang kuat dapat diartikan bahwa model yang dihasilkan adalah baik digunakan untuk melakukan prediksi.

\section{b. Pembahasan}

Pengujian Hipotesis Penelitian

Pada tahap pengujian hipotesis, sangat penting untuk memperhatikan adanya pengaruh langsung dan signifikansi yang ditunjukkan oleh arah anak panah antar variabel laten eksogen terhadap variabel endogen. Variabel eksogen meliputi promosi (X1) dan atribut destinasi (X2). Variabel place branding (Y1) sebagai intervening. Variabel endogen keputusan berkunjung ke destinasi wisata (Y2). Untuk keperluan pengujian hipotesis penelitian ditampilkan Tabel 7 yang memuat path koefisien, t-statistics dan P-value yang bersumber dari Lampiran 9.

Tabel 7. Path Coefficients, T-Statistics, P-Values

\begin{tabular}{|c|c|c|c|c|}
\hline & $\begin{array}{l}\text { Original } \\
\text { Sample }(0)\end{array}$ & $\begin{array}{l}\mathrm{T} \\
\text { Statistics } \\
(\mid 0 / \text { STDEV } \mid)\end{array}$ & $\begin{array}{c}\mathrm{P} \\
\text { Values }\end{array}$ & Signifikansi \\
\hline $\mathrm{X} 1$-> Y1 ( $\beta 1)$ & 0,438 & 7,098 & 0,000 & Signifikan \\
\hline$X 2$-> Y1 ( $\beta 2)$ & 0,499 & 6,626 & 0,000 & Signifikan \\
\hline X1 -> Y2 ( $\beta 3)$ & 0,145 & 1,603 & 0,055 & NonSignifikan \\
\hline $\mathrm{X} 2$-> Y2 ( $\beta 4)$ & 0,270 & 3,429 & 0,000 & Signifikan \\
\hline $\mathrm{Y} 1$-> Y2 ( $\beta 5)$ & 0,428 & 4,646 & 0,000 & Signifikan \\
\hline
\end{tabular}

Sumber: Gambar 1 dan Lampiran 9 (bootstraping)

\section{Pengujian Hipotesis 1: Promosi (X1) Berpengaruh Positip Terhadap Place Branding (Y1)}

Hipotesis yang menyatakan pengaruh positip dinotasikan dengan $\beta i>0$, dengan demikian maka akan dilakukan uji satu sisi yaitu sisi kanan. Ha diterima atau $\mathrm{HO}$ ditolak jika thitung $>$ tkritis dan $\mathrm{P}<\alpha$. Mengacu pada tabel-t pada (Blalock Jr, 1985) untuk ukuran sampel diatas 100 pada tingkat kesalahan $(\alpha)=5 \%$ untuk uji satu sisi diperoleh koefisien ttabel atau tkritis $=1,658$. Untuk pengujian hipotesis pengaruh positip promosi terhadap place branding

\section{Pengujian Hipotesis 2: Atribut Destinasi (X2) Berpengaruh Positip Terhadap Place Branding (Y1)}

Hipotesis yang menyatakan pengaruh positip dinotasikan dengan $\beta i>0$, dengan demikian maka akan dilakukan uji satu sisi yaitu sisi kanan. Ha diterima atau $\mathrm{HO}$ ditolak jika thitung $>$ tkritis dan $\mathrm{P}<\alpha$. Mengacu pada tabel-t dalam (Blalock Jr, 1985) untuk ukuran sampel di atas 100 pada tingkat kesalahan $(\alpha)=5 \%$ untuk uji satu sisi diperoleh koefisien ttabel atau tkritis $=1,658$. Untuk pengujian hipotesis pengaruh positip atribut destinasi terhadap place branding

\section{Pengujian Hipotesis 3: Promosi (X1) berpengaruh positip terhadap keputusan berkunjung ke destinasi wisata (Y2)}

Hipotesis yang menyatakan pengaruh positip dinotasikan dengan $\beta i>0$, dengan demikian maka akan dilakukan uji satu sisi yaitu sisi kanan. Ha diterima atau $\mathrm{HO}$ ditolak jika thitung $>$ tkritis dan $\mathrm{P}<\alpha$. Mengacu pada tabel-t dalam (Blalock Jr, 1985) untuk ukuran sampel diatas 120 pada tingkat kesalahan $(\alpha)=5 \%$ untuk uji satu sisi diperoleh koefisien ttabel atau tkritis $=1,658$. Untuk pengujian hipotesis pengaruh positip promosi terhadap keputusan berkunjung ke destinasi wisata

\footnotetext{
Pengujian Hipotesis 4: Atribut Destinasi (X2) Berpengaruh Positip Terhadap Keputusan Berkunjung Ke Destinasi Wisata (Y2)

Hipotesis yang menyatakan pengaruh positip dinotasikan dengan $\beta i>0$, dengan demikian maka akan dilakukan uji satu sisi yaitu sisi kanan. Ha diterima atau $\mathrm{HO}$ ditolak jika thitung $>$ tkritis dan $\mathrm{P}<\alpha$. Mengacu pada tabel-t dalam (Blalock Jr, 1985) untuk ukuran sampel diatas 100 pada tingkat kesalahan $(\alpha)=5 \%$ untuk uji satu sisi diperoleh koefisien ttabel atau tkritis $=1,658$. Untuk pengujian hipotesis pengaruh positip atribut destinasi terhadap keputusan berkunjung ke destinasi wisata
} 


\section{Pengujian Hipotesis 5: Place Branding (Y1) Berpengaruh Positip Terhadap Keputusan Berkunjung Ke Destinasi Wisata (Y2)}

Hipotesis yang menyatakan pengaruh positip dinotasikan dengan $\beta i>0$, dengan demikian maka akan dilakukan uji satu sisi yaitu sisi kanan. Ha diterima atau $\mathrm{H} 0$ ditolak jika thitung $>$ tkritis dan $\mathrm{P}<\alpha$. Mengacu pada tabel-t pada (Blalock Jr, 1985) untuk ukuran sampel diatas 100 pada tingkat kesalahan $(\alpha)=5 \%$ untuk uji satu sisi diperoleh koefisien ttabel atau tkritis $=1,658$. Untuk pengujian hipotesis pengaruh positip place branding terhadap keputusan berkunjung ke destinasi wisata

\section{Pengaruh Variabel Eksogen terhadap Variabel Endogen}

Penelitian ini melibatkan dua buah variabel eksogen, yaitu promosi (X1) dan atribut destinasi (X2), serta dua buah variabel endogen, yaitu Place branding (Y1) dan keputusan berkunjung ke destinasi wisata (Y2). Variabel endogen Place branding (Y1) memiliki dua buah prediktor yaitu promosi (X1) dan atribut destinasi (X2). Sedangkan, variabel endogen keputusan berkunjung ke destinasi wisata (Y2) memiliki tiga buah prediktor yaitu promosi (X1), atribut destinasi (X2) dan place branding (Y1).

Pada model penelitian tersebut, terlihat variabel place branding (Y1) selain berperan sebagai variabel endogen, berperan juga sebagai variabel eksogen. Dengan demikian variabel place branding (Y1) memiliki posisi sebagai variabel mediator.

\section{Pengaruh Promosi dan Atribut Destinasi terhadap Place Branding}

Untuk mengetahui pengaruh promosi (X1) dan atribut destinasi (X2) terhadap place branding (Y1) berpedoman pada besarnya path coefficiens $(\beta)$. Pada Gambar 1 terlihat besarnya path coefficiens untuk pengaruh promosi $(\mathrm{X} 1)(\beta 1=0,438)$ dan pengaruh atribut destinasi $(\mathrm{X} 2)(\beta 2=0,499)$. Mengacu pada path coefficient $\beta 1$ dan $\beta 2$, dapat dibuat persaman struktural promosi dan atribut destinasi terhadap place branding sebagai berikut.

$\mathrm{Y}=\beta 1 \mathrm{X} 1+\beta 2 \mathrm{X} 2+\mathrm{e} 1$

$\mathrm{Y}=0,438 \mathrm{X} 1+0,499 \mathrm{X} 2+\mathrm{e} 1$

Dengan demikian, dapat dijelaskan bahwa terdapat pola pengaruh positip promosi terhadap place branding, dan terdapat pengaruh positip atribut destinasi terhadap place branding. Artinya, jika promosi dan atribut destinasi membaik atau meningkat maka capaian place branding akan meningkat pula. Begitu pula sebaliknya, jika terjadi penurunan.

Berhubung koefisien $\beta 1=0,438$ dan $\beta 2=0,499$ ini berarti capaian dan pengembangan place branding lebih dominan dipengaruhi oleh atribut destinasi. Artinya dalam upaya pengembangan place branding, atribut destinasi adalah $=0,499 / 0,438=1,14$ (satu koma empat belas) kali lebih dominan dibandingkan dengan promosi.

Pengaruh Promosi, Atribut destinasi dan Place Branding terhadap Keputusan Berkunjung Ke Destinasi Wisata

Untuk mengetahui pengaruh promosi (X1), atribut destinasi (X2) dan Place branding (Y1) dan terhadap keputusan berkunjung ke destinasi wisata (Y2) berpedoman pada besarnya path coefficiens $(\beta)$. Pada Gambar 1 terlihat besarnya path coefficiens untuk pengaruh promosi $(X 1)(\beta 3=0,145)$, untuk pengaruh atribut destinasi $(X 2)(\beta 4=0,270)$ dan untuk pengaruh place branding (Y1) $(\beta 5=0,428)$. Mengacu pada path coefficient $\beta 3, \beta 4$, dan $\beta 5$ dapat dibuat persaman struktural promosi, atribut destinasi dan place branding terhadap keputusan berkunjung ke destinasi wisata sebagai berikut.

$\mathrm{Z}=\beta 3 \mathrm{X} 1+\beta 4 \mathrm{X} 2+\beta 5 \mathrm{Y} 1+\mathrm{e} 2$

$\mathrm{Z}=0,145 \mathrm{X} 1+0,270 \mathrm{X} 2+0,428 \mathrm{Y} 1+\mathrm{e} 2$

Dengan demikian, dapat dijelaskan bahwa terdapat pola pengaruh positip promosi, atribut destinasi dan place branding terhadap keputusan berkunjung ke destinasi wisata. Artinya, jika promosi, atribut destinasi dan place branding, semakin baik atau semakin meningkat maka tingkat keputusan berkunjung ke destinasi wisata akan meningkat pula. Begitu pula sebaliknya jika terjadi penurunan. Berhubung place branding memiliki path coefficiens paling besar $(\beta 4=0,428)$, berarti kontribusi place branding paling dominan dalam peningkatan keputusan berkunjung ke destinasi wisata dibandingkan dengan variabel lainnya. Perbandingan kontribusi place branding dengan atribut promosi sebesar $=0,428 / 0,145=2,95$ kali. Dibandingkan dengan atribut destinasi sebesar $=0,428 / 0,270=1,59$ kali. Hal ini berarti dengan tercapainya tingkat keputusan berkunjung ke destinasi wisata yang didukung promosi, atribut destinasi dan place branding telah mampu menciptakan dan memelihara tingkat keputusan berkunjung ke destinasi wisata. 


\section{Pengujian Effect size}

Gravetter \& Wallnau, (2004), ketika peneliti melaporkan efek signifikansi secara statistika, mereka perlu melaporkan juga ukuran efeknya (effect size). Untuk melihat efek setiap konstruk laten eksogen terhadap variabel endogennya, dapat digunakan evaluasi effect size (f2). Effect size dalam Jogiyanto \& Abdilah, (2015) didefinisikan sebagai kekuatan hubungan atau pengaruh antara variabel indevenden dengan variabel dependen. Tabel 8 berikut menunjukkan koefisien effect size dari masing-masing hubungan variabel eksogen terhadap variabel endogen. Cohen, (1988) membagi effect size berdasarkan tiga kriteria yaitu 0,02-0,14 (kecil), 0,15-0,35 (sedang), dan >0,35 (besar).

Tabel 8. Koefisien effect size (f-square)

\begin{tabular}{lrr}
\hline Hubungan Antar Konstruk & fSquare & $\begin{array}{r}\text { Kategori } \\
\text { Efek }\end{array}$ \\
\hline Promosi $\rightarrow$ Place branding $(\mathrm{X} 1 \rightarrow \mathrm{Y} 1)$ & 0,201 & Sedang \\
Atribut destinasi $\rightarrow$ Place branding $(\mathrm{X} 2 \rightarrow \mathrm{Y} 1)$ & 0,260 & Sedang \\
Promosi $\rightarrow$ Keputusan Berkunjung ke Destinasi Wisata $(\mathrm{X} 1 \rightarrow \mathrm{Y} 2)$ & 0,009 & Kecil \\
$\begin{array}{l}\text { Atribut destinasi } \rightarrow \text { Keputusan Berkunjung ke Destinasi Wisata } \\
(\mathrm{X} 2 \rightarrow \mathrm{Y} 2)\end{array}$ & 0,029 & Kecil \\
$\begin{array}{l}\text { Place branding } \rightarrow \text { Keputusan Berkunjung ke Destinasi Wisata } \\
(\mathrm{Y} 1 \rightarrow \mathrm{Y} 2)\end{array}$ & 0,088 & Kecil \\
\hline
\end{tabular}

\section{Simpulan dan Saran \\ a. Simpulan}

Bahwa promosi berpengaruh positip dan signifikan terhadap place branding. Promosi yang terdiri dari, publikasi, word of mouth, iklan serta E-commerce, yang menunjukan apresiasi serta pengaruh yang cukup tinggi terhadap place branding di obyek wisata Tirta Empul, Tampaksiring. Atribut destinasi berpengaruh positip dan signifikan terhadap place branding. Keberadaan atraksi wisata yang menarik, lokasi yang mudah dijangkau, harga tiket masuk obyek wisata yang pas, keberadaan akomodasi serta produk kenagan memberikan tanggapan/apresiasi yang tinggi dari wisatawan yang berkunjung ke obyek wisata Tirta Empul, Tampaksiring. Promosi berpengaruh positip dan tidak signifikan terhadap keputusan berkunjung ke destinasi wisata. Bahwa kegiatan promosi melalui publikasi, word of mouth, iklan serta Ecommerce, tidak menjadi pertimbangan bagi wisatawan untuk memutus-kan mengunjungi obyek wisata Tirta Empul, Tampaksiring. Atribut destinasi berpengaruh positip dan signifikan terhadap keputusan berkunjung ke destinasi wisata. Hal ini menunjukan bahwa atraksi wisata yang menarik, lokasi yang mudah dijangkau, harga tiket masuk obyek wisata yang pas, keberadaan akomodasi serta produk kenagan menjadi pertimba-ngan yang sangat dominan/utama dari wisatawan untuk memutuskan berkunjung ke obyek wisata Tirta Empul, Tampaksiring. Place branding berpengaruh positip dan signifikan terhadap keputusan berkunjung ke destinasi wisata. Disamping atribut destinasi yang menjadi pertimbangan bagi wisatawan untuk berkunjung ke obyek wisata Tirta Empul, Tampaksiring yakni lingkungan yang nyaman dan asri, udara yang segar, serta kondisi alam dengan pemandangan yang hijau, serta faktor keamanan juga terjamin.

Pembentukan place branding lebih dominan dipengaruhi oleh atribut destinasi. Maksudnya yakni bahwa kondisi obyek wisata Tirta Empul yang asri, nyaman, serta lingkungan yang bersih sangat ditunjang oleh keberadaan destinasi ini yang lokasinya mudah dijangkau, harga tiket masuk obyek wisata yang pas, keberadaan akomodasi serta produk kenagan yang memadai. Pengambilan keputusan berkunjung ke destinasi wisata lebih dominan dipengaruhi oleh place branding. Jadi dalam hal ini yang sangat mendasar bagi wisatawan dalam memutuskan untuk mengunjungi obyek wisata Tirta Empul yakni karena lingkungan yang nyaman dan asri, udara yang segar, serta kondisi alam dengan pemandangan yang hijau, dan juga faktor keamanannya yang sangat terjaga dengan baik.

\section{b. Saran}

Keberadaan obyek wisata Tirta Empul dengan lingkungan yang nyaman dan asri, udara yang segar, serta kondisi alam dengan pemandangan yang hijau, dan juga faktor keamanannya yang sangat terjaga dengan baik selama ini agar tetap dipertahankan untuk penyempurnaan destinasi wisata Tirta Empul ke 
depannya. Keputusan berkunjung wisatawan ke destinasi wisata Tirta Empul ini hendaknya menjadi hal yang dominan bagi perkembangan destinasi wisata Tirta Empul ini tentunya dengan keterlibatan para stakeholder yakni pemerintah, masyarakat, dan para pemerhati wisata, para akademisi, dan juga tak kalah penting yakni para prajuru adat yang memang keseharianya melayani para wisatawan spiritual yang sangat dominan mengunjungi obyek wisata Tirta Empul ini.

\section{KontribusiPenelitian}

Hasil analisis dalam penelitian ini menyebutkan bahwa pengambilan keputusan wisatawan dipengaruhi oleh Place Branding dan Atribut Destinasi, sehingga dapat dijadikan acuan atau landasan oleh pengelola dalam mendesain strategi pemasaran Destinasi Wisatan (DTW) Pura Tirta Empul Tampaksiring Gianyar.

\section{Ucapan Terimakasih}

Terimakasih yang sebesar besarnya kepada Rektor IPB Internasional Bapak Dr. I Made Sudjana, SE.,MM yang telah membiayai penelitian internal, karena kebijakannya semua Dosen mendapat kesempatan untuk mendapatkan hibah internal. Ucapan terima kasih juga kepada Kepala LP2M IPB Internasional Ibu Dr. Denok Lestari, M.Hum. Ucapan terimakasih juga kepada Sekda Kabupaten Gianyar Bapak I Made Gede Wisnu Wijaya, SE.,MM atas arahan dan masukannya.

\section{Daftar Rujukan}

Ardika, I. W. (n.d.). Corresponding Author: ardika52@yahoo.co.id.

Armstrong, G., Kotler, P., \& Da Silva, G. (2006). Marketing: An Introduction: An Asian Perspective. Pearson/Prentice Hall.

Astrama, I. M., \& Mahayasa, I. G. A. (2021). Kajian Strategi Pemasaran Obyek Wisata Gunung Kawi Tampaksiring Kabupaten Gianyar Ditinjau dari Persepsi Wisatawan. Widya Manajemen, 3(1), 39-56.

Blalock Jr, H. M. (1985). Causal models in panel and experimental designs. Aldine de Gruyter.

Buchory, H. A., \& Saladin, D. (2010). Manajemen Pemasaran. Bandung: Linda Karya.

Cohen, J. (1988). Statistical power analysis for the behavioural sciences, 2nd edn.(Hillsdale, NJ: L. Erlbaum Associates).

Eugenio-Martin, J. L., Martín Morales, N., \& Scarpa, R. (2004). Tourism and economic growth in Latin American countries: A panel data approach.

Geisser, S. (1974). A predictive approach to the random effect model. Biometrika, 61(1), 101-107.

Ghozali, I. (2011). Aplikasi analisis multivariate dengan program IBM. Spss.

Gravetter, F. J., \& Wallnau, L. B. (2004). Statistics for the social sciences. Belmont, CA: Wadsworth.

Hair, J. F., Black, W. C., Babin, B. J., Anderson, R. E., \& Tatham, R. L. (2006). Multivariate data analysis 6th Edition. New Jersey: Prentice Hall.

Henslowe, P. (2003). Public relations: A practical guide to the basics. Kogan Page Publishers.

JarrakPost.com. (2020, July). Siap Buka, Sekda Gianyar Tinjau Bali Safari and Marine Park dan Obyek Wisata Tirta. pp. 1-6. Retrieved from https://jarrakpos.com/01/07/2020/siap-buka-sekda-gianyar-tinjaubali-safari-and-marine-park-dan-obyek-wisata-tirta-empul/

Jogiyanto, P., \& Abdilah, W. (2015). DR. Partial Least Square (PLS) dalam Penelitian Bisnis. Yogyakarta: CV Andi Offset.

Kotler, P. (2016). A framework for marketing management. Pearson Education Limited.

Kotler, P., \& Keller, K. L. (2021). Manajemen Pemasaran edisi 13 jilid 2.

NusaBali.com. (2019, November). A Step-By-Step Guide Tiket Objek Naik, Tirta Empul Tetap Ramai Valuta Asing. pp. 1-7. Retrieved from https://www.nusabali.com/berita/63335/tiket-objek-naik-tirtaempul-tetap-ramai

Setiadi, N. J. (2003). Perilaku konsumen: Konsep dan implikasi untuk strategi dan penelitian pemasaran. Jakarta: Prenada Media, 125.

Setiawan, I. K. (2011). Komodifikasi Pusaka Budaya Pura Tirta Empul dalam konteks Pariwisata Global. Disertasi, Program Pendidikan Doktor, Program Pascasarjana Universitas Udayana, Denpasar.

Stone, M. (1974). Cross-validatory choice and assessment of statistical predictions. Journal of the Royal Statistical Society: Series B (Methodological), 36(2), 111-133.

Tjiptono, F. (2008). Strategi Pemasaran Edisi 3. Yogyakarta: Andi.

Tjiptono, F. (2012). Service Management: Mewujudkan Layanan Prima Edisi 2. Yogyakarta: Andi.

Windia11, W., Sumiyati, I. K., Tika, I. W., \& Sedana, G. (n.d.). PEMBENTUKAN FORUM KOORDINASI DALAM RANGKA PEMBENAHAN PENGELOLAAN KAWASAN WARISAN BUDAYA DUNIA (WBD) HULU DAS PAKERISAN. 